Review Article

\title{
Interpatient Variability in Dexmedetomidine Response: A Survey of the Literature
}

\author{
Samantha F. Holliday, ${ }^{1}$ Sandra L. Kane-Gill, ${ }^{2}$ Philip E. Empey, ${ }^{2}$ \\ Mitchell S. Buckley, ${ }^{3}$ and Pamela L. Smithburger ${ }^{2}$ \\ ${ }^{1}$ University of Pittsburgh School of Pharmacy, 3501 Terrace Street, Pittsburgh, PA 15261, USA \\ ${ }^{2}$ Department of Pharmacy and Therapeutics, University of Pittsburgh School of Pharmacy, 3501 Terrace Street, \\ Pittsburgh, PA 15261, USA \\ ${ }^{3}$ Banner Good Samaritan Medical Center, Department of Pharmacy, 1111 E. McDowell Road, Phoenix, AZ 85006, USA
}

Correspondence should be addressed to Pamela L.Smithburger; smithburgerpl@upmc.edu

Received 28 August 2013; Accepted 22 October 2013; Published 16 January 2014

Academic Editors: Y. Hayashi, B. Laviolle, and C. Weissman

\begin{abstract}
Copyright (C) 2014 Samantha F. Holliday et al. This is an open access article distributed under the Creative Commons Attribution License, which permits unrestricted use, distribution, and reproduction in any medium, provided the original work is properly cited.

Fifty-five thousand patients are cared for in the intensive care unit (ICU) daily with sedation utilized to reduce anxiety and agitation while optimizing comfort. The Society of Critical Care Medicine (SCCM) released updated guidelines for management of pain, agitation, and delirium in the ICU and recommended nonbenzodiazepines, such as dexmedetomidine and propofol, as first line sedation agents. Dexmedetomidine, an alpha-2 agonist, offers many benefits yet its use is mired by the inability to consistently achieve sedation goals. Three hypotheses including patient traits/characteristics, pharmacokinetics in critically ill patients, and clinically relevant genetic polymorphisms that could affect dexmedetomidine response are presented. Studies in patient traits have yielded conflicting results regarding the role of race yet suggest that dexmedetomidine may produce more consistent results in less critically ill patients and with home antidepressant use. Pharmacokinetics of critically ill patients are reported as similar to healthy individuals yet wide, unexplained interpatient variability in dexmedetomidine serum levels exist. Genetic polymorphisms in both metabolism and receptor response have been evaluated in few studies, and the results remain inconclusive. To fully understand the role of dexmedetomidine, it is vital to further evaluate what prompts such marked interpatient variability in critically ill patients.
\end{abstract}

\section{Introduction}

Five million patients are admitted to the intensive care unit (ICU) in the United States annually, and over 55,000 patients are cared for daily [1]. The number one reason for admission is respiratory failure/insufficiency, which often necessitates mechanical ventilation with the need of sedative medications [1]. Sedation in the ICU is utilized to optimize patient care by reducing anxiety, reducing agitation, and maximizing patient comfort and safety [2-8]. Previously, heavily sedating patients was a common practice in the ICU with the belief that it would help patients tolerate mechanical ventilation; however, currently, lighter sedation has been emphasized [9].

Oversedation is associated with increased time on the mechanical ventilator and length of stay in the ICU [9-11].
However, undersedation can be associated with severe patient agitation resulting in longer durations of ICU stay, time on mechanical ventilation, physiological stress, and increased rates of self-extubation [12, 13]. Undersedation may also result in hypercatabolism, suppressed immune system, and increased sympatholysis [9]. Achieving a balance between the two extremes is vital to optimize patient care.

In 2013, the Society of Critical Care Medicine (SCCM) released updates to the guidelines for management of pain, agitation, and delirium in the ICU. Lighter sedation coupled with daily sedation awakenings and measurement of sedation levels was emphasized. Opioids followed by non-benzodiazepines such as dexmedetomidine and propofol were recommended as first line agents for analgosedation [11]. Compared to alternative sedatives, benzodiazepines have been 
associated with increased time to liberation from the mechanical ventilator, hospitalization days, and risk of developing ICU-related delirium [11, 14-16].

Dexmedetomidine is a potent alpha-2 agonist and up to 8 times more selective than clonidine, an alpha agonist, for the alpha-2 receptor [17-25]. In contrast to benzodiazepines, recent large clinical trials have highlighted the benefits of dexmedetomidine including more delirium-free and comafree days [4], a lighter sedation described as "cooperative sedation," [20-31] and an opioid sparing analgesia with no added respiratory depression [18-25, 27-30, 32-38]. Both propofol and dexmedetomidine offer the advantage of easy titration and a relatively short half-life [11]. These non-benzodiazepine sedatives are not without concerns for adverse effects including hypotension and bradycardia [7].

Although dexmedetomidine use has increased over the years, its role in clinical practice is mired by observations that the ability to achieve sedation goals is not consistent amongst all patients. In the MIDEX and PRODEX trials, Jakob and colleagues noted that there was a lack of efficacy in at least 1 out of 8 patients [7]. Other studies have noted failure rates as high as $21 \%$ and $50 \%[8,39]$. The reasons for the wide variability in clinical response are unclear; however, several hypotheses have been considered. This paper reviews the available data regarding the role of patient features/traits, the pharmacokinetic differences present in critically ill patients, and the specific contribution of genetic polymorphisms to altered pharmacokinetics and pharmacodynamics.

\section{Individual Patient Features/Traits}

The first hypothesis to be considered is that there are individual patient differences, not solely explained by genetic differences or pharmacokinetics, that produce the interpatient variability in response to dexmedetomidine (Table 1). Several studies have been conducted analyzing race, gender, and other unique characteristics with conflicting results. A retrospective study of 85 dexmedetomidine infusions in critically ill patients found that non-Black race was associated with a higher rate of intolerance/failure (odds ratio of 9.5; 95\% CI 1.16-77.91, $P=0.03$ ) and a reported intolerance/failure rate of $21 \%$ [8]. However, a prospective observational study in 73 healthy individuals found no association between race and intolerance/failure $(P>0.16)$ [40]. Genetic differences are linked to ethnicities and may explain the different response rates seen in the retrospective study [41-45]. Since both population sizes were small, it is difficult to ascertain the true relationship.

Three pharmacokinetic studies (Table 2) analyzed several covariates in the pharmacokinetic models. The first study in 13 patients showed that in patients with a lower baseline Simplified Acute Physiology Score (SAPS II), clearance of dexmedetomidine was higher and half-life shorter [46]. In the second study of 21 patients, a multivariate analysis found that dexmedetomidine clearance decreased with decreasing cardiac output and increasing age. Patients with low albumin concentrations also had an increased volume of distribution [47]; this was supported by a third study of 527 patients [48]. However, the third study also found no correlation between dexmedetomidine clearance and cardiac output or age. Only body weight was considered a strong predictor of dexmedetomidine clearance [48].

Smithburger and colleagues conducted a six month prospective, observational study evaluating dexmedetomidine effectiveness and if any variables were associated with drug response. Thirty-eight mechanically ventilated patients were analyzed. Thirty-two patients were Caucasian, and 19 patients were female. Overall, dexmedetomidine was ineffective in 19 (50\%) of patients and effective in 11 (28.95\%). The remaining eight cases $(21 \%)$ were unable to be analyzed due to confounding variables affecting mental status. A lower Modified Acute Physiology and Chronic Health Evaluation (APACHE II) score and home antidepressant use were identified as significant factors for effective sedation with dexmedetomidine. Patients with higher APACHE II scores may require higher levels of sedation [39].

Other studies support the finding that dexmedetomidine should be used in patients requiring lighter sedation $[3,6]$. Less information, however, is available about the interaction between home antidepressant use and alpha- 2 agonists. It has been noted that antagonism of alpha receptors can decrease the time to effect for antidepressants while it is suggested that activation of alpha receptors may increase the time to effect $[49,50]$. New antidepressants and antipsychotics have also been evaluated for their efficacy as alpha-2 receptors and antagonists [51,52]. The interaction between dexmedetomidine and antidepressants, however, has not been fully understood and more research into underlying interactions and clinical impact is needed.

Overall, there is limited information about patient features or traits affecting response to dexmedetomidine. The two small studies that evaluated the role of race in response to dexmedetomidine reported opposite results. Few studies have identified covariates that may explain the wide range of interpatient variability. Hopefully, larger studies will take results from these pilot studies, such as from Smithburger and colleagues, and attempt to evaluate their validity.

\section{Pharmacokinetics of Critically Ill Patients}

The second hypothesis to be considered is that the variability in dexmedetomidine response can be explained by differences in the drug pharmacokinetics in critically ill individuals. Although the pharmacokinetics of healthy and postoperative patients have been evaluated, little data are present for critically ill patients. In healthy volunteers, dexmedetomidine has a linear, dose-independent pharmacokinetic profile [20, $21,23-25,30,53]$. It rapidly distributes in 6 minutes [18$22,24,25,28,30]$, is highly protein bound $[19-25,28,30]$, and has a volume of distribution at steady state of $1.33 \mathrm{~L} / \mathrm{kg}[19$, $22,28]$ or $118 \mathrm{~L}[20,21,24,25]$. Dexmedetomidine is almost completely metabolized in the liver by cytochrome $\mathrm{P} 450$ (CYP) enzyme 2A6 and uridine diphosphate glucuronosyltransferase (UGTs) glucuronidation pathways, specifically UGT1A4 and UGT2B10, to inactive metabolites [19-25, 28, 54]. Its estimated clearance is $39 \mathrm{~L} / \mathrm{hr}[25,30]$, and the elimination half-life is $2-2.5$ hours [18-22, 24, 25, 28, 30]. Pharmacokinetics of dexmedetomidine do not vary with age, 
TABLE 1: Studies evaluating the role of patient features/traits.

\begin{tabular}{|c|c|c|c|c|c|}
\hline Citation & $\begin{array}{l}\text { Study } \\
\text { design }\end{array}$ & Population & Objective & Intervention & Results \\
\hline $\begin{array}{l}\text { Tellor et al. } \\
\text { (2012) [8] }\end{array}$ & $\mathrm{R}, \mathrm{O}$ & $\begin{array}{l}\text { (i) } 75 \mathrm{MV} \text { adults with } 85 \\
\text { episodes of DEX } \\
\text { infusion. } \\
\text { (ii) Included } 50 \\
\text { Caucasian and } 15 \text { Black } \\
\text { patients. }\end{array}$ & $\begin{array}{l}\text { To describe rates of DEX } \\
\text { intolerance/failure and } \\
\text { identify patient predictors } \\
\text { of intolerance/failure. }\end{array}$ & $\begin{array}{l}\text { (i) All patients received } \\
\text { DEX titrated by the bedside } \\
\text { nurse from } 0.2 \mathrm{mcg} / \mathrm{kg} / \mathrm{h} \text { to } \\
\text { a maximum of } 1.5 \mathrm{mcg} / \mathrm{kg} / \mathrm{h} \\
\text { to achieve targeted sedation } \\
\text { with rescue fentanyl, } \\
\text { midazolam, and propofol } \\
\text { permissible. } \\
\text { (ii) Individual episodes of } \\
\text { DEX infusions were } \\
\text { analyzed for predefined } \\
\text { descriptions of intolerance } \\
\text { and failure. } \\
\text { (iii) Multivariate logistic } \\
\text { regression analysis was } \\
\text { used to identify predictors } \\
\text { of intolerance or failure. }\end{array}$ & $\begin{array}{l}\text { (i) } 18 \text { episodes }(21 \%) \text { were } \\
\text { classified as } \\
\text { intolerance/failure. } 67 \\
\text { episodes ( } 79 \% \text { ) were } \\
\text { classified as successful. } \\
\text { (ii) No significant } \\
\text { difference between success } \\
\text { and intolerance groups in } \\
\text { additional sedation use was } \\
\text { noted. } \\
\text { (iii) Non-Black race was } \\
\text { found to be statistically } \\
\text { significant (adjusted odds } \\
\text { ratio 9.5; } 95 \% \text { CI } 1.16-77.91 \text {; } \\
P=0.03 \text { ) as a predictor of } \\
\text { failure/intolerance. The } \\
\text { clinical significance of this } \\
\text { was questionable. }\end{array}$ \\
\hline
\end{tabular}

(i) Patients received 3 placebo infusions then 3 DEX infusions (0.1, 0.15, $0.15 \mathrm{mcg} / \mathrm{kg}$ for total of $0.4 \mathrm{mcg} / \mathrm{kg}$ )

(ii) BP, HR, and plasma NE concentrations were measured at the end of the infusion then $10 \mathrm{~min}$ and 20 min after.

(iii) DEX plasma levels were measured after the las infusion of DEX.

(iv) Patients were grouped into ADRA-2C del322-325 or no deletion and GNB3 C825T or no polymorphism.

(i) All patients received DEX to achieve targeted sedation based upon unit sedation protocol.

(ii) Doses ranged from $0.3 \mathrm{mcg} / \mathrm{kg} / \mathrm{hr}$ to $1.4 \mathrm{mcg} / \mathrm{kg} / \mathrm{hr}$ with rescue propofol, fentanyl, and benzodiazepines allowed. (iii) Individual episodes of DEX infusions were analyzed for predefined descriptions of intolerance and failure.

(iv) Multivariate logistic regression analysis used to identify predictors of intolerance or failure. (i) DEX was ineffective in 19 (50\%) patients. It was effective in 11 (28.95\%) patients. In the remaining patients $(n=8)$, an analysis was unable to be completed.

(ii) No significant difference between success and intolerance groups in additional sedation use was noted.

(iii) Lower APACHE II score ( $\beta$ coefficient -0.24 ; $95 \% \mathrm{CI},-0.39$ to -0.03$)$ and home antidepressant use $(\beta$ coefficient 2.33; 95\% CI, 0.23 to 4.43 ) were identified as positive patient specific characteristics.

R: retrospective; O: observational; P: prospective; MV: mechanically ventilated; DEX: dexmedetomidine; CV: cardiovascular; BP: blood pressure; HR: heart rate; NE: norepinephrine; ADRA-2C: alpha adrenergic receptor 2C; APACHE II: A Modified Acute Physiology and Chronic Health Evaluation. 
TABLE 2: Studies evaluating pharmacokinetics in critically ill patients.

\begin{tabular}{|c|c|c|c|c|c|}
\hline Citation & $\begin{array}{c}\text { Study } \\
\text { Design }\end{array}$ & Population & Objective & Intervention & Results \\
\hline $\begin{array}{l}\text { Iirola et al. } \\
\text { (2011) [46] }\end{array}$ & $\mathrm{P}, \mathrm{O}$ & $\begin{array}{l}\text { (i) } 13 \text { ICU patients. } \\
\text { (ii) All Caucasian. }\end{array}$ & $\begin{array}{l}\text { To describe PK of } \\
\text { prolonged ( }>24 \mathrm{hrs} \text { ) and } \\
\text { HD DEX in critically ill } \\
\text { patients and to determine if } \\
\text { a linear relationship } \\
\text { remains. }\end{array}$ & $\begin{array}{l}\text { (i) All patients received } \\
\text { DEX at a constant rate for } \\
\text { the first } 12 \text { hours (doses } \\
\text { were } 0.1,0.2,0.45 \text {, or } \\
0.7 \mathrm{mcg} / \mathrm{kg} / \mathrm{hr} \text { with no LD) } \\
\text { then titrated by bedside } \\
\text { nurse to goal sedation } \\
\text { score. The dose allowed was } \\
0.1-2.5 \mathrm{mcg} / \mathrm{kg} / \mathrm{hr} \text {. } \\
\text { (ii) DEX plasma levels were } \\
\text { obtained at predefined } \\
\text { times. }\end{array}$ & $\begin{array}{l}\text { (i) DEX retained a linear } \\
\text { relationship at doses of } \\
2.5 \mathrm{mcg} / \mathrm{kg} / \mathrm{hr}\left(r^{2}=0.95\right) \text {. } \\
\text { (ii) } \mathrm{PK} \text { parameters } \\
\text { remained similar to those } \\
\text { reported in healthy } \\
\text { individuals. } \\
\text { (iii) A multivariate analyses } \\
\text { showed a significant } \\
\text { difference in higher Cls } \\
(P=0.006) \text { and shorter } \\
\text { elimination half-life } \\
(P=0.036) \text { with lower } \\
\text { baseline SAPS II }(<42) \\
\text { score. }\end{array}$ \\
\hline $\begin{array}{l}\text { Iirola et al. } \\
\text { (2012) [47] }\end{array}$ & $\mathrm{P}, \mathrm{O}$ & 21 ICU patients. & $\begin{array}{l}\text { To describe PK of } \\
\text { prolonged ( }>48 \text { hrs) DEX } \\
\text { infusions in critically ill } \\
\text { patients. }\end{array}$ & $\begin{array}{l}\text { (i) All patients received a } \\
\mathrm{LD} \text { of } 3-6 \mathrm{mcg} / \mathrm{kg} / \mathrm{hr} \text { over } \\
10 \mathrm{~min} \text { then a maintenance } \\
\text { infusion of } \\
0.1-2.5 \mathrm{mcg} / \mathrm{kg} / \mathrm{hr} \text { titrated } \\
\text { by bedside nurse to desired } \\
\text { sedation. } \\
\text { (ii) DEX plasma levels were } \\
\text { obtained at predefined } \\
\text { times. }\end{array}$ & $\begin{array}{l}\text { (i) PK parameters remained } \\
\text { similar to those reported in } \\
\text { healthy individuals. } \\
\text { (ii) The elimination Cls was } \\
57.0 \mathrm{~L} / \mathrm{hr}(42.1,65.6) \text { and } V_{\text {ss }} \\
\text { was } 132 \mathrm{~L}(96,189) \text {. } \\
\text { (iii) A multivariate analyses } \\
\text { showed that DEX Cls } \\
\text { decreased with decreasing } \\
\mathrm{CO} \text { and increasing age } \\
(P=0.009) \text {; } V_{\text {ss }} \text { was } \\
\text { increased in patients with } \\
\text { low albumin concentration } \\
(P=0.002) \text {. }\end{array}$ \\
\hline $\begin{array}{l}\text { Välitalo } \\
\text { et al. } \\
\text { (2013) [48] }\end{array}$ & $\mathrm{P}, \mathrm{O}$ & $\begin{array}{l}\text { (i) } 527 \text { ICU patients } \\
\text { enrolled in phase III } \\
\text { studies of prolonged } \\
\text { (>24 hrs) DEX } \\
\text { infusion. } \\
\text { (ii) } 96 \% \text { were } \\
\text { Caucasian. }\end{array}$ & $\begin{array}{l}\text { To describe PK of } \\
\text { prolonged ( }>24 \text { hrs) DEX } \\
\text { infusions in critically ill } \\
\text { patients. }\end{array}$ & $\begin{array}{l}\text { (i) All patients received an } \\
\text { initial infusion of } \\
0.7 \mu \mathrm{g} / \mathrm{kg} / \mathrm{h} \text { for } 1 \text { hour then } \\
\text { a maintenance infusion of } \\
0.2-1.4 \mu \mathrm{g} / \mathrm{kg} / \mathrm{h} \text { titrated by } \\
\text { bedside nurse to desired } \\
\text { sedation. } \\
\text { (ii) Maximum duration of } \\
\text { infusion was } 14 \text { days. } \\
\text { (iii) DEX plasma levels } \\
\text { were obtained at baseline, } \\
1 \text { hr after beginning } \\
\text { treatment, and then the } \\
\text { same time each day. } \\
\text { Samples were taken } 24 \text { and } \\
48 \text { hours after infusion } \\
\text { ended. }\end{array}$ & $\begin{array}{l}\text { (i) PK parameters remained } \\
\text { similar to those reported in } \\
\text { healthy individuals. } \\
\text { (ii) The strongest covariate } \\
\text { relationship was between } \\
\text { DEX Cls and body weight. } \\
\text { (iii) A multivariate analysis } \\
\text { showed an inverse } \\
\text { relationship between } \\
\text { plasma albumin and } V_{\text {ss }} \text {; } \\
\text { however, this relationship } \\
\text { did not account for } \\
\text { interpatient variability. } \\
\text { (iv) DEX Cls was not } \\
\text { affected by CO or } \\
\text { concentration levels. }\end{array}$ \\
\hline
\end{tabular}

P: prospective, O: observational; ICU: intensive care unit; PK: pharmacokinetics; HD: high dose; DEX: dexmedetomidine; LD: loading dose; Cls: clearance; SAPS II: Simplified Acute Physiology Score; CO: cardiac output; $V_{\text {ss }}$ : volume of distribution at steady state.

gender, or renal dysfunction in healthy volunteers $[20-22,25$, $30,55]$.

It is vital to investigate pharmacokinetics of dexmedetomidine in critically ill patients because evidence from healthy individuals demonstrates a dose-dependent response for sedation [53, 56-59]. A study demonstrated an increased sedation of $38 \%$ and $65 \%$ with the first two doses of dexmedetomidine that reached a targeted plasma level of $0.5 \mathrm{ng} / \mathrm{mL}$ and $0.8 \mathrm{ng} / \mathrm{mL}$, respectively, in healthy individuals [57]. It is believed that the therapeutic range is up to $1.2 \mathrm{ng} / \mathrm{mL}$ but higher levels may be tolerated [60]. The relationship between dexmedetomidine concentrations and sedation levels is described as exponential (exponent $<1$ ). The highest plasma concentrations $(1.23 \pm 0.29 \mathrm{ng} / \mathrm{mL})$ increased cognitive performance time by a factor of two in healthy individuals [56]. 
Critical illness is known to alter drug pharmacokinetics [61]. End-organ damage and changes in hemodynamics, electrolytes, and hormones may alter medication dose-response relationships $[17,48,62]$. A study completed in postoperative patients suggested that pharmacokinetics remained similar to healthy individuals [63]. Three studies in critically ill patients suggest a wide variability in dexmedetomidine pharmacokinetics (Table 2) [46-48].

Iirola and colleagues examined the pharmacokinetics of long-term ( $>24$ hour) high dose dexmedetomidine in 13 critically ill, Caucasian patients. They concluded that although the mean elimination half-life and clearance remained similar to those reported in healthy individuals, there was wide interpatient variability [46]. A second study by Iirola and colleagues examined the pharmacokinetics of prolonged ( $>48$ hours) dexmedetomidine infusions in 21 critically ill patients and reported values similar to the first study. The elimination clearance (95\% confidence interval) was $57 \mathrm{~L} / \mathrm{hr}(42.1,65.6)$, and volume of distribution at steady state was $132 \mathrm{~L}(96,189)$ [47]. A third, larger study examined pharmacokinetics of prolonged ( $>24$ hours) dexmedetomidine infusions in 527 patients and concluded that pharmacokinetics of the critically ill remained similar to healthy individuals. Again, there was very wide interpatient variability (coefficients of variation of approximately $60 \%$ for both volume of distribution and clearance) that was not fully explained by covariates. The strongest predictor of dexmedetomidine clearance was body weight [48].

As the three pharmacokinetic studies showed wide interpatient variability in dexmedetomidine plasma levels, it is important to question if adequate plasma levels are reached in critically ill patients. Recent trials have used higher doses $(>0.7 \mathrm{mcg} / \mathrm{kg} / \mathrm{hr})$ to obtain desired sedation levels $[4,5,7$, $32,64]$. This suggests that adequate plasma levels have not been obtained; however, a retrospective study concluded that critically ill patients treated with high dose dexmedetomidine (doses $>0.7 \mathrm{mcg} / \mathrm{kg} / \mathrm{hr}$ ) had more Richmond Agitation Sedation Scale (RASS) scores outside of targeted sedation than those treated with low dose (doses $\leq 0.7 \mathrm{mcg} / \mathrm{kg} / \mathrm{hr}$ ). They did not collect plasma levels [65]. Since the plasma level studies were completed in healthy individuals and the retrospective study was completed in a small population without plasma levels, it is difficult to ascertain if appropriate plasma levels were reached. More studies are needed to evaluate if a goal dexmedetomidine level is ideal and if it is being achieved in critically ill patients.

\section{Genetic Polymorphisms}

4.1. Metabolism. The third hypothesis to explain the variability of response to dexmedetomidine is that there are clinically-relevant genetic polymorphisms in metabolism. Dexmedetomidine is metabolized by CYP2A6, which is also responsible for the metabolism of coumarin, valproic acid, and nicotine. CYP2A6 can be induced by phenobarbital and dexamethasone [66]. Several polymorphisms with significant interindividual and interracial variations that affect drug metabolism have been reported [41, 66-68]. A meta-analysis by Carter and colleagues reported that CYP $2 \mathrm{~A} 6{ }^{*} 2$ was more common in individuals of European descent (1-3\%) and rare in the Asian population. In contrast, the polymorphism CYP2A6* 4 was more common in individuals of Asian descent (15-20\%) and rare in Caucasian populations [41, 42]. Both alleles are associated with poor metabolism $[42,67,68]$. Due to the paucity of substrates, the importance of polymorphisms in CYP2A6 is not well understood. However, this may contribute to dexmedetomidine's clinical response variability [42]. Two studies have evaluated the role of CYP2A6 polymorphisms in dexmedetomidine metabolism (Table 3).

Kohli and colleagues examined the role of polymorphisms of CYP2A6 on dexmedetomidine disposition using a Bayesian hierarchical mixture pharmacokinetic model of dexmedetomidine blood levels. Their investigation included 43 mechanically-ventilated patients that were enrolled in the MENDS trial and were being cared for in the medical and surgical ICUs [4]. This patient population consisted primarily of Caucasian individuals, accounting for 38 of the 43 enrolled, and five Black individuals. Patients were grouped into three categories: normal metabolizers $(n=33)$, intermediate metabolizers $(n=5)$, or slow metabolizers $(n=2)$. The authors concluded that clearance was not altered significantly by differences in polymorphisms of CYP2A6 [69]. A second study incorporated CYP2A6 pharmacogenomic genotypes into a population pharmacokinetic model and found no improvement in the goodness of fit [62].

Both studies determined that there was no significant difference or no effect of polymorphisms on dexmedetomidine metabolism, but these studies suffer from a small patient population size and lack of ethnic diversity. Both studies included only 43 patients with little to no representation of Asian ethnicity, where much variability is found $[62,69]$. In order to have a more comprehensive picture of the effects of CYP2A6, a larger, more diverse population size is needed.

A second route of metabolism for dexmedetomidine is through glucuronidation by UGTs [54, 74]. Less is known about the importance and the variability in UGTs than the cytochrome P450 enzymes [75]. However, it has been demonstrated that there are polymorphisms in phase II metabolism, specifically UGTs and that these differences may affect drug metabolism [74-81].

Dexmedetomidine is metabolized by UGT1A4 and UGT2B10 [54, 74]. These enzymes are primarily involved in $\mathrm{N}$-glucuronidation of endogenous estrogens and eicosanoids and of exogenous antidepressants and nicotine [74, 75]. Polymorphic differences have been implicated in patient intervariability for lamotrigine [79], valproic acid [78], and olanzapine [80]. While several polymorphisms have been identified, only two, UGT1A4* 2 and UGT1A4* 3 , have been identified as altering function of the enzyme. There is limited and conflicting data regarding the functional impact of these polymorphisms. For example, for UGT1A4*2, a study by Ehmer and colleagues noted decreased enzymatic activity for beta-naphthylamine [82]; yet Wiener and colleagues noted an increased enzymatic activity for 4-(methylnitrosamino)-1(3-pyridyl)-1-butanol [83]. Like with CYP2A6, the polymorphism frequencies appear to be ethnically linked $[77,78]$. 
TABLE 3: Studies evaluating role of genetic polymorphisms.

\begin{tabular}{|c|c|c|c|c|}
\hline Citation & $\begin{array}{l}\text { Study } \\
\text { design }\end{array}$ & $\begin{array}{c}\text { Gene } \\
\text { studied }\end{array}$ & Population & Objective \\
\hline $\begin{array}{l}\text { Kohli } \\
\text { et al. } \\
(2012) \\
{[69]}\end{array}$ & $\mathrm{P}, \mathrm{O}$ & CYP2A6 & $\begin{array}{l}43 \mathrm{MV} \text { patients } \\
\text { in medical and } \\
\text { surgical ICU } \\
\text { (38 Caucasian } \\
\text { and } 2 \text { Black). }\end{array}$ & $\begin{array}{l}\text { To determine the } \\
\text { effect of CYP2A6 } \\
\text { polymorphisms on } \\
\text { DEX Cls. }\end{array}$ \\
\hline
\end{tabular}

Intervention Results

\begin{tabular}{|c|c|c|c|c|}
\hline $\begin{array}{l}\text { Choi } \\
\text { et al. } \\
\text { (2011) } \\
{[62]}\end{array}$ & $\mathrm{P}, \mathrm{O}$ & CYP2A6 & $\begin{array}{l}43 \text { critically ill } \\
\text { patients. }\end{array}$ & $\begin{array}{l}\text { To develop a new } \\
\text { population PK } \\
\text { model to more } \\
\text { accurately } \\
\text { accommodate } \\
\text { outliers. }\end{array}$ \\
\hline
\end{tabular}

To evaluate the clinical effect of the

\begin{tabular}{|c|c|c|c|}
\hline $\begin{array}{l}\text { Yağar } \\
\text { et al. } \\
\text { (2011) }\end{array}$ & $\mathrm{P}, \mathrm{O}$ & $\begin{array}{c}\text { ADRA- } \\
2 \mathrm{~A}\end{array}$ & $\begin{array}{c}110 \text { patients } \\
\text { undergoing } \\
\text { CABG. }\end{array}$ \\
\hline
\end{tabular}
ADRA-2A C-1291G polymorphism on DEX response via HD effects and sedation. (i) All patients received DEX.

(ii) Patients grouped into normal

( $n=33)$, intermediate $(n=5)$, or slow $(n=2)$ metabolizers.

(iii) Cls determined via median of five plasma DEX concentrations.

(i) All patients received DEX titrated by the bedside nurse from $0.15 \mathrm{mcg} / \mathrm{kg} / \mathrm{h}$ to a maximum of $1.5 \mathrm{mcg} / \mathrm{kg} / \mathrm{h}$ to achieve targeted sedation.

(ii) Serum levels were collected at three specific, predefined times (05:00 \pm 2 h, 10:00 \pm 2 hrs, 16:00 \pm $2 \mathrm{~h})$.

(i) All patients received DEX after surgery once in the ICU to a targeted infusion rate of

No significant difference in DEX amongst normal $(48.5 \mathrm{~L} / \mathrm{h}$; 39.8-58.7 L/hr), intermediate (56.9 L/hr; 31.6-94. $4 \mathrm{~L} / \mathrm{hr}$ ) or slow (86.2 L/hr; 26.9-218.7 L/hr)

metabolizers.

Presented as (median; 95\% credible interval)

$1.4 \mathrm{mcg} / \mathrm{kg} / \mathrm{hr}$.

(ii) HD effects (SAP, DAP, HR)

monitored via routine invasive monitoring.

(iii) Sedation effects monitored via

BIS and RSS.

(iv) Patients were grouped into $G$ allele carriers and noncarriers.
Incorporation of CYP2A6 genotype as a covariate did not alter the population pharmacokinetics.
Kurnik

et al.

(2011)

$$
\mathrm{P}, \mathrm{O} \text { ADRA- }
$$

$2 \mathrm{~A}$

[45]
To evaluate the clinical effect of ADRA-2A polymorphisms on CV effects of DEX by changes in SBP and plasma NE concentrations. (i) Patients received 3 placebo infusions then $3 \mathrm{DEX}$ infusions $(0.1,0.15,0.15 \mathrm{mcg} / \mathrm{kg}$ for total of $0.4 \mathrm{mcg} / \mathrm{kg}$ ).

(ii) SBP and plasma NE

concentrations were measured 10 min after infusion.

(iii) Patients were grouped into 9 different polymorphisms. (i) No significant difference in HD (SAP, DAP, HR) effects.

(ii) Patients with C-1291-G polymorphisms had higher BIS $(P<0.05)$ after $30 \mathrm{~min}$ and RSS $(P<0.05)$ after $55-60 \mathrm{~min}$ starting infusion, showing a longer period to fall asleep or a decrease in DEX effect.

(i) After a sensitivity analysis, individuals who were homozygous or carriers of HT3 had a $39 \%$ ( 0.61 fold) smaller decrease $(\triangle \mathrm{SBP}=$

$8.8 \pm 6.5 \mathrm{mmHG}$ and $14.5 \pm 6.1 \mathrm{mmHG}$, respectively; $P=0.015)$ in SBP after DEX. Individuals who were homozygous for HT4 had an $82 \%$ (1.8 fold) larger decrease $(\triangle \mathrm{SBP}=$ $24.7 \pm 8.1 \mathrm{mmHG}$ compared to $13.6 \pm 5.9 \mathrm{mmHG}$ for non-carriers; $P=0.007$ ).

(ii) There was no difference in plasma NE levels.

To evaluate the presence of the ethnic differences in the response to DEX through the clinical effect of ADRA-2C

Kurnik et al. (2008) $\mathrm{P}, \mathrm{O} \quad \mathrm{ADRA}-$
73 healthy individuals ( 37 Caucasians, 36 Blacks). del322-325

polymorphism and

G-protein GNB3

C825T

polymorphism on

$\mathrm{CV}$ effects by

changes in BP and

$\mathrm{HR}$ and plasma NE concentrations. (i) Patients received 3 placebo infusions then 3 DEX infusions $(0.1,0.15,0.15 \mathrm{mcg} / \mathrm{kg}$ for total of $0.4 \mathrm{mcg} / \mathrm{kg}$ ).

(ii) BP, HR, and plasma NE concentrations were measured at the end of the infusion the and $20 \mathrm{~min}$ after

(iii) Patients were grouped into ADRA-2C del322-325 or no deletion and GNB3 C825T or no polymorphism.
No significant differences in BP, $\mathrm{HR}$, and plasma NE concentrations for both ADRA-2C del322-325 and GNB3 C825T polymorphism were detected. 
TABLe 3: Continued.

\begin{tabular}{|c|c|c|c|c|c|c|}
\hline Citation & $\begin{array}{l}\text { Study } \\
\text { design }\end{array}$ & $\begin{array}{c}\text { Gene } \\
\text { studied }\end{array}$ & Population & Objective & Intervention & Results \\
\hline $\begin{array}{l}\text { Kohli } \\
\text { et al. } \\
(2010) \\
{[71]}\end{array}$ & $\mathrm{P}, \mathrm{O}$ & $\begin{array}{c}\text { ADRA- } \\
2 \mathrm{C}\end{array}$ & $\begin{array}{c}73 \text { healthy } \\
\text { individuals ( } 37 \\
\text { Caucasians, } 36 \\
\text { Blacks). }\end{array}$ & $\begin{array}{l}\text { To evaluate the } \\
\text { clinical effect of } \\
\text { several ADRA-2C } \\
\text { polymorphisms on } \\
\text { pain perception and } \\
\text { cognitive responses. }\end{array}$ & $\begin{array}{l}\text { (i) Pain rating via VAS from a cold } \\
\text { pressor test before infusions and } \\
30 \text { min after the final DEX } \\
\text { infusion. } \\
\text { (ii) Cognitive responses were } \\
\text { measured before the infusions, } \\
10 \text { min after the placebo and DEX } \\
\text { infusions. } \\
\text { (iii) Patients received } 3 \text { placebo } \\
\text { infusions then } 3 \text { DEX infusions } \\
\text { (0.1, } 0.15,0.15 \mathrm{mcg} / \mathrm{kg} \text { for total of } \\
0.4 \text { mcg/kg). } \\
\text { (iv) Patients were grouped into five } \\
\text { different polymorphisms, } \\
\text { including ADRA-2C del322-325. }\end{array}$ & $\begin{array}{l}\text { (i) VAS scores from patients with } \\
\text { del322-325 were significantly } \\
\text { higher than any other } \\
\text { polymorphism }(P=0.012) \text {. } \\
\text { (ii) DEX lowered mean pain } \\
\text { scores significantly (from } \\
4.8 \pm 2.1 \mathrm{~cm} \text { to } 4.1 \pm 2.1 \text {, } \\
P<0.001 \text { ). } \\
\text { (iii) The change in pain score after } \\
\text { DEX administration was not } \\
\text { significantly associated with any } \\
\text { genotype. } \\
\text { (iv) No genotype, especially } \\
\text { del322-325, was significantly } \\
\text { associated with differences in } \\
\text { sedation scores or memory } \\
\text { response. }\end{array}$ \\
\hline
\end{tabular}

(i) Patients were grouped into wt/wt $(n=28)$, wt/del $(n=13)$, del/del $(n=8)$.

(ii) Patients received DEX at increasing doses ranging from $0.01-1000 \mathrm{ng} / \mathrm{min}$.

To examine the clinical effect of Muszkat $\begin{array}{llcr}\text { et al. } & \text { P, O } & \text { ADRA- } & 49 \text { healthy } \\ (2005) & \text { 2B } & \text { individuals. }\end{array}$ [72]

(iii) Venoconstriction was (dose that produced $50 \%$ of
ADRA-2B del

301-303

polymorphism on vascular response.
To determine if adrenergic vasoconstriction

Muszkat

et al. (2011) $\mathrm{P}, \mathrm{O}$ $\alpha-1$ and $\alpha-2$

62 healthy

[73]

\section{individuals (28}

Caucasian, 34 Blacks). sensitivity through

$\alpha 1$ and $\alpha 2$ receptors

are determined

through mechanism downstream from the receptor and thus linked. measured via LVDT and the $\mathrm{ED}_{50}$ maximum venoconstriction or $E_{\max }$ ) was calculated. (iv) Maximum venoconstriction was the percentage of reduction in vein diameter from maximal dilation.

(i) Patients received either DEX at (i) Median $\mathrm{ED}_{50}$ for DEX was increasing doses ranging from $0.01-100 \mathrm{ng} / \mathrm{min}$ or phenylephrine $0.45-5.37 \mathrm{ng} / \mathrm{min}$ ) and for

(i) There was no difference in $\mathrm{ED}_{50}$ and $E_{\max }$ among the three groups.

(ii) The $\mathrm{ED}_{50}$ for wt/wt was

$1.39 \mathrm{ng} / \mathrm{min}(95 \% \mathrm{CI}$

0.03-63 ng/min), for wt/del $1.63 \mathrm{ng} / \mathrm{min}$ (95\% CI

$0.01-177.8 \mathrm{ng} / \mathrm{min})$, and for $\mathrm{del} / \mathrm{del}$ $2.37 \mathrm{ng} / \mathrm{min}$ (95\% CI $0.17-33.7$ $\mathrm{ng} / \mathrm{min}$ )

(iii) The $E_{\max }$ for wt/wt was $75.4 \pm 14.9 \%$, for $w t / d e l$ $75.7 \pm 21.3 \%$, for $\mathrm{del} / \mathrm{del}$ $82.2 \pm 12.9 \%$ $1.32 \mathrm{ng} / \mathrm{min}$ (IQR at increasing doses ranging from phenylephrine was $177.8 \mathrm{ng} / \mathrm{min}$ $12-12000 \mathrm{ng} / \mathrm{min}$.

(ii) Venoconstriction was (IQR $40.7-436.5 \mathrm{ng} / \mathrm{min}$ ).

(ii) There was no correlation measured via LVDT and the $\mathrm{ED}_{50}$ between $\mathrm{ED}_{50}$ (individual (dose that produced $50 \%$ of maximum venoconstriction or $\left.E_{\max }\right)$ was calculated.

(iii) Maximum venoconstriction (iii) The $E_{\max }$ for DEX was $80.0 \%$ was the percentage of reduction in $(64.7-95.2 \%)$ and for vein diameter from maximal phenylephrine was $90.8 \%$ dilation. sensitivity) for DEX and phenylephrine before and after covariates.

(64.7-95.2\%) and for (82.2-99.6\%).

P: prospective; O: observation; MV: mechanical ventilation, ICU: intensive care unit; DEX: dexmedetomidine; Cls: clearance; PK: pharmacokinetic; CABG: coronary artery bypass graft; ADRA-2A: alpha adrenergic receptor 2A; HD: hemodynamic; SAP: systolic arterial pressure; DAP: diastolic arterial pressure; HR: heart rate; ICU: intensive care unit; BIS: bispectral index; RSS: Ramsay Sedation Scale; CV: cardiovascular; SBP: systolic blood pressure; NE: norepinephrine; BP: blood pressure; VAS: visual analogue scale; IQR: interquartile range.

The second enzyme, UGT2B10, is less understood than UGT1A4, and there are fewer studies evaluating possible effects of polymorphisms [84]. The enzyme was just recently discovered in 2007 [54, 74, 75, 84]. Berg and colleagues examined the effect of UGT2B10 polymorphisms, specifically the single nucleotide polymorphism (SNP) Asp67Tyr, on nicotine metabolism. They noted that the polymorphism
Asp67Tyr was associated with skewed amounts of metabolites and with higher oxidative metabolites [81].

Dexmedetomidine is believed to be more extensively metabolized by UGT1A4 than UGT2B10 [54, 74]. The implications of this information are currently unknown as no studies have been done comparing polymorphic differences in glucuronidation metabolism in dexmedetomidine. 
Information is also lacking regarding cytochrome-mediated metabolism of dexmedetomidine. The only study to date was completed in a small group of patients with limited ethnic variability. More information in this area is desperately needed to grasp a fuller understanding of metabolism polymorphisms [75].

4.2. Pharmacodynamics. Genetic differences in each of the subtypes of the alpha- 2 receptors may also affect patient response to dexmedetomidine [85]. Since an alpha subtype specific agent has not been identified, the specific roles of each of the receptors have been difficult to define. It is currently known that Alpha-2A (ADRA-2A) is responsible for suppressing sympathetic flow from the brain producing a decrease in blood pressure, heart rate, and cardiac output. It also produces antinociceptive, sedative, and anxiolytic effects $[21,23,25,28,86,87]$. It also inhibits norepinephrine release from sympathetic nerve endings [86]. Alpha-2B (ADRA-2B) is responsible for vasoconstriction $[22,29,72,86]$. Alpha 2-C (ADRA-2C) is responsible for mediating dopamine neurotransmission $[86,87]$.

If a genetic difference produced a receptor with a lower affinity to dexmedetomidine, then a higher concentration of dexmedetomidine would be necessary to produce the same response seen in a wild-type (wt) receptor. These genetic differences may also produce nonfunctioning receptors which would not produce a response from dexmedetomidine. In order to examine these polymorphisms, researchers have examined all three subtypes to see if polymorphisms could be responsible for large interpatient variability in response to dexmedetomidine (Table 3).

Two important polymorphisms have been identified for ADRA2A $[88,89]$. The first genetic polymorphism is ADRA2A -1291C/G SNP [89]. This SNP has been investigated in attention deficit hyperactivity disorder (ADHD) as well as other behavioral conditions such as Tourette's [43, 90]. It has also been implicated in interpatient variability to medications such as weight gain in antipsychotics [91] and antidepressant response to milnacipran [92]. Ethnic differences have been identified for this polymorphism [4345]. A second common polymorphism, C753G transversion, has not been studied in dexmedetomidine [88].

Yağar and colleagues examined the effects of ADRA2A C1291G polymorphism on dexmedetomidine response in 110 patients undergoing a coronary artery bypass graft (CABG). Patients were monitored with bispectral index (BIS) monitor and Ramsey Sedation Score (RSS) every five minutes; once RSS $\leq 2$, dexmedetomidine $1.4 \mathrm{mcg} / \mathrm{kg} / \mathrm{hr}$ IV was given. Thirty minutes after the beginning of the dexmedetomidine infusion, the BIS scores were higher and RSS scores lower for patients carrying the $\mathrm{G}$ allele. This indicated that the patients with the $\mathrm{G}$ allele were less sedated than those with the $\mathrm{C}$ allele, and this difference was statistically significant. There was no genetic difference for differences in blood pressure or heart rate response to dexmedetomidine [70].

The results of this study were supported by a prospective, observational study in 73 healthy individuals. It analyzed nine different ADRA2A variants and concluded that certain polymorphisms were associated with statistically significant differences $(P=0.007)$ in changes in blood pressure [45].

Although the main effects of dexmedetomidine have been attributed to ADRA2A, researchers have also examined the effects of polymorphisms in ADRA2C and ADRA2B. For ADRA2C, the deletion of the four amino acids 322-325 has been identified and associated with a decrease in function [40, 93-95]. For dexmedetomidine, a nonfunctioning ADRA2C would imply a decrease in the inhibition of norepinephrine release and spinal analgesia producing decreased effectiveness [86, 93-95]. A prospective, observational study of 73 healthy individuals, however, concluded that there was no change in response $(P>0.66)$ for all genotypes [40]. This study was supported by a second prospective, observational study that found no difference in analgesic effects of dexmedetomidine in patients with wild-type and del322-325 ADRA2C [71].

The receptor ADRA-2B, mainly responsible for constriction, has also been evaluated for genetic polymorphisms to see if these could be implicated in interpatient variability $[72,86]$. For ADRA-2B, one important deletion variation, del301-303, results in a desensitized receptor [72, 85, 96-101]. If a patient had a desensitized receptor, then it is thought that he/she would not respond as easily to plasma catecholamines. Since dexmedetomidine can inhibit norepinephrine release, less catecholamine could result in less vasoconstriction and more hypotension $[18,23,24,26,37,38]$.

Muszkat and colleagues examined the effect of the ADRA2B del301-303 receptor (del) and the wt receptor on peripheral vasoconstriction. They hypothesized that there would be a difference in venoconstriction response between wt and del receptors when dexmedetomidine was administered; however, they determined that venoconstriction response of both wt and del receptors was similar [72]. Muszkat and colleagues also evaluated the possibility that a pathway downstream from the receptor, independent of genetic variation, could be responsible. They reasoned that if factors such as concentration of the drug at the active site or effects downstream from the receptor are plausible explanations, then it is reasonable to assume that sensitivity to both alpha-1 and alpha-2 receptors is correlated [73, 102]. Muszkat and colleagues studied the effects of phenylephrine, an alpha-1 receptor agonist, and dexmedetomidine on venoconstriction in the dorsal hand vein. They determined that there was no significant correlation for venoconstriction response to dexmedetomidine. Muszkat and colleagues concluded that alpha- 1 receptors and alpha- 2 receptors are mediated differentially [73]. In a similar study, Posti and colleagues studied the venoconstriction of phenylephrine and dexmedetomidine in the dorsal hand model. They also concluded that the sensitivity and effects of each receptor are mediated separately [102].

More information concerning the differences in receptor polymorphisms has been gathered than in the differences in metabolism; however, understanding of the implications of the receptors' pharmacogenetics remains incomplete. Currently, studies have only been completed in small groups of individuals, and the results are confounded by the lack of a subtype-receptor specific agonist or antagonist. Research in 
other disease states such as ADHD has implicated polymorphisms of receptors as affecting response. This suggests that receptor polymorphisms are not yet well understood and may hold the key as to why there is certain interpatient variability. While all three receptor subtypes have been evaluated, ADRA-2A appears to be the primary receptor activated and responsible for effects. More studies evaluating receptor polymorphisms in ADRA-2A as well as the other two receptors are needed to determine if this is a plausible explanation.

\section{Conclusion and Future Direction}

It is difficult to characterize what prompts such marked interpatient variability in critically ill patients receiving dexmedetomidine. The few studies that have examined this phenomenon have not produced clinically significant answers to guide clinicians in appropriate patient selection or appropriate dosing. Both dexmedetomidine and propofol are recommended as first line sedatives in the SCCM guidelines. Although dexmedetomidine exhibits beneficial properties and may have some advantages over propofol, reports of treatment failure are concerning. Therefore, further research into individual patient features/traits, pharmacokinetics, and genetic polymorphisms, potentially impacting dexmedetomidine's efficacy, is vital to better define its role in therapy and to better optimize patient care.

\section{Conflict of Interests}

The authors declare that there is no conflict of interests regarding the publication of this paper.

\section{Acknowledgments}

Grant support was provided by the National Institutes of Health awards KL2TR000146 (PE). The content is solely the responsibility of the authors and does not necessarily represent the official views of the National Institutes of Health.

\section{References}

[1] Society of Critical Care Medicine, "Communications: critical care statistics," http://www.sccm.org/Communications/Pages/ CriticalCareStats.aspx.

[2] R. MacLaren, L. K. Forrest, and T. H. Kiser, "Adjunctive dexmedetomidine therapy in the intensive care unit: a retrospective assessment of impact on sedative and analgesic requirements, levels of sedation and analgesia, and ventilatory and hemodynamic parameters," Pharmacotherapy, vol. 27, no. 3, pp. 351-359, 2007.

[3] E. Ruokonen, I. Parviainen, S. M. Jakob et al., "Dexmedetomidine versus propofol/midazolam for long-term sedation during mechanical ventilation," Intensive Care Medicine, vol. 35, no. 2, pp. 282-290, 2009.

[4] P. P. Pandharipande, B. T. Pun, D. L. Herr et al., "Effect of sedation with dexmedetomidine vs lorazepam on acute brain dysfunction in mechanically ventilated patients: the MENDS randomized controlled trial," The Journal of the American Medical Association, vol. 298, no. 22, pp. 2644-2653, 2007.

[5] R. R. Riker, Y. Shehabi, P. M. Bokesch et al., "Dexmedetomidine vs midazolam for sedation of critically Ill patients A randomized trial," The Journal of the American Medical Association, vol. 301, no. 5, pp. 489-499, 2009.

[6] S. Devabhakthuni, M. Pajoumand, C. Williams, J. A. Kufera, K. Watson, and D. M. Stein, "Evaluation of dexmedetomidine: safety and clinical outcomes in critically Ill trauma patients," Journal of Trauma, vol. 71, no. 5, pp. 1164-1171, 2011.

[7] S. M. Jakob, E. Ruokonen, R. M. Grounds et al., "Dexmedetomidine vs midazolamor propofol for sedation during prolonged mechanical ventilation: two randomized controlled trials," The Journal of the American Medical Association, vol. 307, no. 11, pp. 1151-1160, 2012.

[8] B. R. Tellor, H. M. Arnold, S. T. Micek, and M. H. Kollef, “Occurrence and predictors of dexmedetomidine infusion intolerance and failure," Hospital Practice, vol. 40, no. 1, pp. 186-192, 2012.

[9] K. Rowe and S. Fletcher, "Sedation in the intensive care unit," Continuing Education in Anaesthesia, Critical Care and Pain, vol. 8, no. 2, pp. 50-55, 2008.

[10] T. D. Girard, J. P. Kress, B. D. Fuchs et al., "Efficacy and safety of a paired sedation and ventilator weaning protocol for mechanically ventilated patients in intensive care (Awakening and Breathing Controlled trial): a randomised controlled trial," The Lancet, vol. 371, no. 9607, pp. 126-134, 2008.

[11] J. Barr, G. L. Fraser, K. Puntillo et al., "Clinical practice guidelines for the management of pain, agitation, and delirium in adult patients in the intensive care unit," Critical Care Medicine, vol. 41, no. 1, pp. 263-306, 2013.

[12] J. C. Woods, L. C. Mion, J. T. Connor et al., "Severe agitation among ventilated medical intensive care unit patients: frequency, characteristics and outcomes," Intensive Care Medicine, vol. 30, no. 6, pp. 1066-1072, 2004.

[13] D. Cohen, K. Horiuchi, M. Kemper, and C. Weissman, "Modulating effects of propofol on metabolic and cardiopulmonary responses to stressful intensive care unit procedures," Critical Care Medicine, vol. 24, no. 4, pp. 612-617, 1996.

[14] J. W. Devlin, S. Mallow-Corbett, and R. R. Riker, "Adverse drug events associated with the use of analgesics, sedatives, and antipsychotics in the intensive care unit," Critical Care Medicine, vol. 38, no. 6, supplement, pp. S231-S243, 2010.

[15] G. L. Weinhouse and P. L. Watson, "Sedation and sleep disturbances in the ICU," Critical Care Clinics, vol. 25, no. 3, pp. 539549, 2009.

[16] S. B. Patel and J. P. Kress, "Sedation and analgesia in the mechanically ventilated patient," American Journal of Respiratory and Critical Care Medicine, vol. 185, no. 5, pp. 486-497, 2012.

[17] D. B. Coursin, D. B. Coursin, and G. A. Maccioli, "Dexmedetomidine," Current Opinion in Critical Care, vol. 7, no. 4, pp. 221226, 2001.

[18] P. Pandharipande, E. W. Ely, and M. Maze, "Dexmedetomidine for sedation and perioperative management of critically ill patients," Seminars in Anesthesia, Perioperative Medicine and Pain, vol. 25, no. 2, pp. 43-50, 2006.

[19] P. M. Szumita, S. A. Baroletti, K. E. Anger, and M. E. Wechsler, "Sedation and analgesia in the intensive care unit: evaluating the role of dexmedetomidine," American Journal of Health-System Pharmacy, vol. 64, no. 1, pp. 37-44, 2007. 
[20] R. Gertler, H. C. Brown, D. H. Mitchell, and E. N. Silvius, "Dexmedetomidine: a novel sedative-analgesic agent," Proceedings (Baylor University. Medical Center), vol. 14, no. 1, pp. 13-21, 2001.

[21] T. V. S. P. Murthy and R. Singh, "Alpha 2 adrenoceptor agonistdexmedetomidine role in anaesthesia and intensive care: a clinical review," Journal of Anaesthesiology Clinical Pharmacology, vol. 25, no. 3, pp. 267-272, 2009.

[22] O. Panzer, V. Moitra, and R. N. Sladen, "Pharmacology of sedative-analgesic agents: dexmedetomidine, remifentanil, ketamine, volatile anesthetics, and the role of peripheral mu antagonists," Critical Care Clinics, vol. 25, no. 3, pp. 451-469, 2009.

[23] N. Bhana, K. L. Goa, and K. J. McClellan, "Dexmedetomidine," Drugs, vol. 59, no. 2, pp. 263-268, 2000.

[24] M. A. Haselman, "Dexmedetomidine: a useful adjunct to consider in some high-risk situations," AANA Journal, vol. 76, no. 5, pp. 335-339, 2008.

[25] S. M. Hoy and G. M. Keating, "Dexmedetomidine: a review of its use for sedation in mechanically ventilated patients in an intensive care setting and for procedural sedation," Drugs, vol. 71, no. 11, pp. 1481-1501, 2011.

[26] A. T. Gerlach and J. F. Dasta, "Dexmedetomidine: an updated review," Annals of Pharmacotherapy, vol. 41, no. 2, pp. 245-254, 2007.

[27] J. Mantz, J. Josserand, and S. Hamada, "Dexmedetomidine: new insights," European Journal of Anaesthesiology, vol. 28, no. 1, pp. 3-6, 2011.

[28] S. B. Yu, "Dexmedetomidine sedation in ICU," Korean Journal of Anesthesiology, vol. 62, no. 5, pp. 405-411, 2012.

[29] R. Maclaren, J. C. Krisl, R. E. Cochrane, and S. W. Mueller, "A case-based approach to the practical application of dexmedetomidine in critically ill adults," Pharmacotherapy, vol. 33, no. 2, pp. 165-186, 2013.

[30] M. Maze, C. Scarfini, and F. Cavaliere, "New agents for sedation in the intensive care unit," Critical Care Clinics, vol. 17, no. 4, pp. 881-897, 2001.

[31] R. M. Venn and R. M. Grounds, "Comparison between dexmedetomidine and propofol for sedation in the intensive care unit: patient and clinician perceptions," British Journal of Anaesthesia, vol. 87, no. 5, pp. 684-690, 2001.

[32] J. R. Guinter and J. L. Kristeller, "Prolonged infusions of dexmedetomidine in critically ill patients," American Journal of Health-System Pharmacy, vol. 67, no. 15, pp. 1246-1253, 2010.

[33] Z. P. Khan, C. N. Ferguson, and R. M. Jones, "Alpha-2 and imidazoline receptor agonists. Their pharmacology and therapeutic role," Anaesthesia, vol. 54, no. 2, pp. 146-165, 1999.

[34] R. M. Venn, C. J. Bradshaw, R. Spencer et al., "Preliminary UK experience of dexmedetomidine, a novel agent for postoperative sedation in the intensive care unit," Anaesthesia, vol. 54, no. 12, pp. 1136-1142, 1999.

[35] J. A. Tan and K. M. Ho, "Use of dexmedetomidine as a sedative and analgesic agent in critically ill adult patients: a metaanalysis," Intensive Care Medicine, vol. 36, no. 6, pp. 926-939, 2010.

[36] R. M. Venn, J. Hell, and R. M. Grounds, "Respiratory effects of dexmedetomidine in the surgical patient requiring intensive care," Critical Care, vol. 4, no. 5, pp. 302-308, 2000.

[37] A. E. Triltsch, M. Welte, P. Von Homeyer et al., "Bispectral index-guided sedation with dexmedetomidine in intensive care: a prospective, randomized, double blind, placebo-controlled phase II study," Critical Care Medicine, vol. 30, no. 5, pp. 10071014, 2002.

[38] P. Talke, R. Chen, B. Thomas et al., "The hemodynamic and adrenergic effects of perioperative dexmedetomidine infusion after vascular surgery," Anesthesia and Analgesia, vol. 90, no. 4, pp. 834-839, 2000.

[39] P. Smithburger, R. B. Smith, S. L. Kane-Gill et al., "Identification of patient predictorsfor dexmedetomidine effectiveness for ICU sedation," American Journal of Critical Care. In press.

[40] D. Kurnik, M. Muszkat, G. G. Sofowora et al., "Ethnic and genetic determinants of cardiovascular response to the selective $\alpha 2$-adrenoceptor agonist dexmedetomidine," Hypertension, vol. 51, no. 2, pp. 406-411, 2008.

[41] B. L. Carter, T. Y. Long, and P. M. Cinciripini, "A meta-analytic review of the CYP2A6 genotype and smoking behavior," Nicotine and Tobacco Research, vol. 6, no. 2, pp. 221-227, 2004.

[42] H. Raunio, A. Rautio, H. Gullstén, and O. Pelkonen, "Polymorphisms of CYP2A6 and its practical consequences," British Journal of Clinical Pharmacology, vol. 52, no. 4, pp. 357-363, 2001.

[43] L. Park, J. T. Nigg, I. D. Waldman et al., "Association and linkage of $\alpha$-2A adrenergic receptor gene polymorphisms with childhood ADHD," Molecular Psychiatry, vol. 10, no. 6, pp. 572580, 2005.

[44] B. Karahalil, E. Coskun, and E. Emerce, "ADRA2A polymorphism and smoking in a Turkish population," Toxicology and Industrial Health, vol. 24, no. 3, pp. 171-176, 2008.

[45] D. Kurnik, M. Muszkat, C. Li et al., "Genetic variations in the $\alpha 2 \mathrm{~A}$-Adrenoreceptor are associated with blood pressure response to the agonist dexmedetomidine," Circulation, vol. 4, no. 2, pp. 179-187, 2011.

[46] T. Iirola, R. Aantaa, R. Laitio et al., "Pharmacokinetics of prolonged infusion of high-dose dexmedetomidine in critically ill patients," Critical Care, vol. 15, no. 5, article R257, 2011.

[47] T. Iirola, H. Ihmsen, R. Laitio et al., "Population pharmacokinetics of dexmedetomidine during long-term sedation in intensive care patients," British Journal of Anaesthesia, vol. 108, no. 3, pp. 460-468, 2012.

[48] P. A. Välitalo, T. Ahtola-sätilä, A. Wighton, T. Sarapohja, P. Pohjanjousi, and C. Garratt, "Population pharmacokinetics of dexmedetomidine in critically ill patients," Clinical Drug Investigation, vol. 33, no. 8, pp. 579-587, 2013.

[49] R. W. Invernizzi and S. Garattini, "Role of presynaptic $\alpha 2$ adrenoceptors in antidepressant action: recent findings from microdialysis studies," Progress in Neuro-Psychopharmacology and Biological Psychiatry, vol. 28, no. 5, pp. 819-827, 2004.

[50] S. U. Yanpallewar, K. Fernandes, S. V. Marathe et al., " $\alpha 2$-adrenoceptor blockade accelerates the neurogenic, neurotrophic, and behavioral effects of chronic antidepressant treatment," Journal of Neuroscience, vol. 30, no. 3, pp. 1096-1109, 2010.

[51] J. Sallinen, I. Höglund, M. Engström et al., "Pharmacological characterization and CNS effects of a novel highly selective alpha2C-adrenoceptor antagonist JP-1302," British Journal of Pharmacology, vol. 150, no. 4, pp. 391-402, 2007.

[52] J. M. Dwyer, B. J. Platt, S. J. Sukoff Rizzo et al., "Preclinical characterization of BRL 44408: antidepressant- and analgesiclike activity through selective $\alpha 2 \mathrm{~A}$-adrenoceptor antagonism," International Journal of Neuropsychopharmacology, vol. 13, no. 9, pp. 1193-1205, 2010. 
[53] S. Lee, B. H. Kim, K. Lim et al., "Pharmacokinetics and pharmacodynamics of intravenous dexmedetomidine in healthy Korean subjects," Journal of Clinical Pharmacology and Therapeutics, vol. 37, no. 6, pp. 698-703, 2012.

[54] S. Kaivosaari, P. Toivonen, O. Aitio et al., "Regio- and stereospecific N-glucuronidation of medetomidine: the differences between UDP glucuronosyltransferase (UGT) 1A4 and UGT2B10 account for the complex kinetics of human liver microsomes," Drug Metabolism and Disposition, vol. 36, no. 8, pp. 1529-1537, 2008.

[55] A. M. De Wolf, R. J. Fragen, M. J. Avram, P. C. Fitzgerald, and F. Rahimi-Danesh, "The pharmacokinetics of dexmedetomidine in volunteers with severe renal impairment," Anesthesia and Analgesia, vol. 93, no. 5, pp. 1205-1209, 2001.

[56] M. S. Angst, B. Ramaswamy, M. F. Davies, and M. Maze, "Comparative analgesic and mental effects of increasing plasma concentrations of dexmedetomidine and alfentanil in humans," Anesthesiology, vol. 101, no. 3, pp. 744-752, 2004.

[57] T. J. Ebert, J. E. Hall, J. A. Barney, T. D. Uhrich, and M. D. Colinco, "The effects of increasing plasma concentrations of dexmedetomidine in humans," Anesthesiology, vol. 93, no. 2, pp. 382-394, 2000.

[58] A. Kallio, M. Scheinin, M. Koulu et al., "Effects of dexmedetomidine, a selective $\alpha 2$-adrenoceptor agonist, on hemodynamic control mechanisms," Clinical Pharmacology and Therapeutics, vol. 46, no. 1, pp. 33-42, 1989.

[59] J. P. Belleville, D. S. Ward, B. C. Bloor, and M. Maze, "Effects of intravenous dexmedetomidine in humans: I. Sedation, ventilation, and metabolic rate," Anesthesiology, vol. 77, no. 6, pp. 1125-1133, 1992.

[60] S. Dutta, R. Lal, M. D. Karol, T. Cohen, and T. Ebert, "Influence of cardiac output on dexmedetomidine pharmacokinetics," Journal of Pharmaceutical Sciences, vol. 89, no. 4, pp. 519-527, 2000.

[61] B. M. Power, A. M. Forbes, P. V. Van Heerden, and K. F. Ilett, "Pharmacokinetics of drugs used in critically ill adults," Clinical Pharmacokinetics, vol. 34, no. 1, pp. 25-56, 1998.

[62] L. Choi, B. S. Caffo, U. Kohli et al., "A Bayesian hierarchical nonlinear mixture model in the presence of artifactual outliers in a population pharmacokinetic study," Journal of Pharmacokinetics and Pharmacodynamics, vol. 38, no. 5, pp. 613-636, 2011.

[63] R. M. Venn, M. D. Karol, and R. M. Grounds, "Pharmacokinetics of dexmedetomidine infusions for sedation of postoperative patients requiring intensive care," British Journal of Anaesthesia, vol. 88 , no. 5, pp. 669-675, 2002.

[64] J. F. Dasta, S. L. Kane-Gill, and A. J. Durtschi, "Comparing dexmedetomidine prescribing patterns and safety in the naturalistic setting versus published data," Annals of Pharmacother$a p y$, vol. 38, no. 7-8, pp. 1130-1135, 2004.

[65] G. M. Jones, C. V. Murphy, A. T. Gerlach, E. M. Goodman, and L. J. Pell, "High-dose dexmedetomidine for sedation in the intensive care unit: an evaluation of clinical efficacy and safety," Annals of Pharmacotherapy, vol. 45, no. 6, pp. 740-747, 2011.

[66] N. Inui, "CYP2A6 (cytochrome P450, family 2, subfamily A, polypeptide 6)," Atlas of Genetics and Cytogenetics in Oncology and Haematology, no. 9, pp. 875-877, 2011.

[67] M. Nakajima, T. Fukami, H. Yamanaka et al., "Comprehensive evaluation of variability in nicotine metabolism and CYP2A6 polymorphic alleles in four ethnic populations," Clinical Pharmacology and Therapeutics, vol. 80, no. 3, pp. 282-297, 2006.

[68] K. A. Schoedel, E. B. Hoffmann, Y. Rao, E. M. Sellers, and R. F. Tyndale, "Ethnic variation in CYP2A6 and association of genetically slow nicotine metabolism and smoking in adult Caucasians," Pharmacogenetics, vol. 14, no. 9, pp. 615-626, 2004.

[69] U. Kohli, P. Pandharipande, M. Muszkat et al., "CYP2A6 genetic variation and dexmedetomidine disposition," European Journal of Clinical Pharmacology, vol. 68, no. 6, pp. 937-942, 2012.

[70] S. Yağar, S. Yavaş, and B. Karahalil, "The role of the ADRA2A C1291G genetic polymorphism in response to dexmedetomidine on patients undergoing coronary artery surgery," Molecular Biology Reports, vol. 38, no. 5, pp. 3383-3389, 2011.

[71] U. Kohli, M. Muszkat, G. G. Sofowora et al., "Effects of variation in the human $\alpha 2 \mathrm{~A}$ - and $\alpha 2 \mathrm{C}$-adrenoceptor genes on cognitive tasks and pain perception," European Journal of Pain, vol. 14, no. 2, pp. 154-159, 2010.

[72] M. Muszkat, G. G. Sofowora, H.-G. Xie, A. J. J. Wood, and C. M. Stein, " $\alpha 2 B$ Adrenergic receptor 301-303 deletion polymorphism and vascular $\alpha 2$ adrenergic receptor response," Pharmacogenetics and Genomics, vol. 15, no. 1, pp. 23-28, 2005.

[73] M. Muszkat, D. Kurnik, G. G. Sofowora, A. J. J. Wood, and C. M. Stein, "Independent regulation of $\alpha 1$ and $\alpha 2$ adrenergic receptor-mediated vasoconstriction in vivo," Journal of Hypertension, vol. 29, no. 2, pp. 251-256, 2011.

[74] S. Kaivosaari, M. Finel, and M. Koskinen, "N-glucuronidation of drugs and other xenobiotics by human and animal UDPglucuronosyltransferases," Xenobiotica, vol. 41, no. 8, pp. 652669, 2011.

[75] K. W. Bock, "Functions and transcriptional regulation of adult human hepatic UDP-glucuronosyl-transferases (UGTs): mechanisms responsible for interindividual variation of UGT levels," Biochemical Pharmacology, vol. 80, no. 6, pp. 771-777, 2010.

[76] M. H. Court, S. X. Duan, L. L. Von Moltke et al., "Interindividual variability in acetaminophen glucuronidation by human liver microsomes: identification of relevant acetaminophen UDPglucuronosyltransferase isoforms," Journal of Pharmacology and Experimental Therapeutics, vol. 299, no. 3, pp. 998-1006, 2001.

[77] N. Hakooz, S. Alzubiedi, A.-M. Yousef et al., "UDP-glucuronosyltransferase 1A4 (UGT1A4) polymorphisms in a Jordanian population," Molecular Biology Reports, vol. 39, no. 7, pp. 7763-7768, 2012.

[78] D. Chatzistefanidis, I. Georgiou, A. P. Kyritsis, and S. Markoula, "Functional impact and prevalence of polymorphisms involved in the hepatic glucuronidation of valproic acid," Pharmacogenomics, vol. 13, no. 9, pp. 1055-1071, 2012.

[79] M. López, P. Dorado, N. Monroy et al., "Pharmacogenetics of the antiepileptic drugs phenytoin and lamotrigine," Drug Metabolism and Drug Interactions, vol. 26, no. 1, pp. 5-12, 2011.

[80] K. K. Erickson-Ridout, J. Zhu, and P. Lazarus, "Olanzapine metabolism and the significance of UGT1A448V and UGT2B1067Y variants," Pharmacogenetics and Genomics, vol. 21, no. 9, pp. 539-551, 2011.

[81] J. Z. Berg, L. B. Von Weymarn, E. A. Thompson et al., "UGT2B10 genotype influences nicotine glucuronidation, oxidation, and consumption," Cancer Epidemiology Biomarkers and Prevention, vol. 19, no. 6, pp. 1423-1431, 2010.

[82] U. Ehmer, A. Vogel, J. K. Schütte, B. Krone, M. P. Manns, and C. P. Strassburg, "Variation of hepatic glucuronidation: novel functional polymorphisms of the UDP-glucuronosyltransferase UGT1A4," Hepatology, vol. 39, no. 4, pp. 970-977, 2004.

[83] D. Wiener, J.-L. Fang, N. Dossett, and P. Lazarus, "Correlation between UDP-glucuronosyltransferase genotypes and 4-(methylnitrosamino)-1-(3-pyridyl)-1-butanone glucuronidation phenotype in human liver microsomes," Cancer Research, vol. 64, no. 3, pp. 1190-1196, 2004. 
[84] Y. Kato, T. Izukawa, S. Oda et al., "Human UDP-glucuronosyltransferase (UGT) $2 \mathrm{~B} 10$ in drug N-glucuronidation: substrate screening and comparison with UGT1A3 and UGT1A4," Drug Metabolism and Disposition, vol. 41, no. 7, pp. 1389-1397, 2013.

[85] I. Belfer, B. Buzas, H. Hipp et al., "Haplotype-based analysis of alpha $2 \mathrm{~A}, 2 \mathrm{~B}$, and $2 \mathrm{C}$ adrenergic receptor genes captures information on common functional loci at each gene," Journal of Human Genetics, vol. 50, no. 1, pp. 12-20, 2005.

[86] T. C. Westfall, "Chapter 8: neurotransmission: the autonomic and somatic motor nervous systems," in Goodman \& Gilman's The Pharmacological Basis of Therapeutics, L. L. Brunton, B. A. Chabner, and B. C. Knollmann, Eds., McGraw-Hill, New York, NY, USA, 12th edition, 2011.

[87] M. Maze and M. Fujinaga, " $\alpha 2$ Adrenoceptors in pain modulation: which subtype should be targeted to produce analgesia?" Anesthesiology, vol. 92, no. 4, pp. 934-936, 2000.

[88] D. Kurnik, M. Muszkat, C. Li et al., "Variations in the alpha2Aadrenergic receptor gene and their functional effects," Clinical Pharmacology and Therapeutics, vol. 79, no. 3, pp. 173-185, 2006.

[89] S. Lario, J. Calls, A. Cases, J. Oriola, A. Torras, and F. Rivera, "MspI identifies a biallelic polymorphism in the promoter region of the $\alpha(2 \mathrm{~A})$-adrenergic receptor gene," Clinical Genetics, vol. 51, no. 2, pp. 129-130, 1997.

[90] J. Stevenson, K. Langley, H. Pay et al., "Attention deficit hyperactivity disorder with reading disabilities: preliminary genetic findings on the involvement of the ADRA2A gene," Journal of Child Psychology and Psychiatry and Allied Disciplines, vol. 46, no. 10, pp. 1081-1088, 2005.

[91] L. Sickert, D. J. Müller, A. K. Tiwari et al., "Association of the $\alpha 2 \mathrm{~A}$ adrenergic receptor-1291C/G polymorphism and antipsychotic-induced weight gain in European-Americans," Pharmacogenomics, vol. 10, no. 7, pp. 1169-1176, 2009.

[92] M. Wakeno, M. Kato, G. Okugawa et al., "The alpha 2Aadrenergic receptor gene polymorphism modifies antidepressant responses to milnacipran," Journal of Clinical Psychopharmacology, vol. 28, no. 5, pp. 518-524, 2008.

[93] R. G. Aleong, W. H. Sauer, A. D. Robertson, S. B. Liggett, and M. R. Bristow, "Adrenergic receptor polymorphisms and prevention of ventricular arrhythmias with bucindolol in patients with chronic heart failure," Circulation, vol. 6, no. 1, pp. 137-143, 2013.

[94] J. Savva, K. Alfakih, S. L. Galloway et al., "The $\alpha 2$ C-Del322325 adrenoceptor polymorphism and the occurrence of left ventricular hypertrophy in hypertensives," Blood Pressure, vol. 21, no. 2, pp. 116-121, 2012.

[95] M. R. Bristow, G. A. Murphy, H. Krause-Steinrauf et al., "An $\alpha 2 \mathrm{C}$-adrenergic receptor polymorphism alters the norepinephrine-lowering effects and therapeutic response of the $\beta$ Blocker Bucindolol in chronic heart failure," Circulation, vol. 3 , no. 1, pp. 21-28, 2010.

[96] P. Heinonen, M. Koulu, U. Pesonen et al., "Identification of a three-amino acid deletion in the $\alpha 2 \mathrm{~b}$-adrenergic receptor that is associated with reduced basal metabolic rate in obese subjects," Journal of Clinical Endocrinology \& Metabolism, vol. 84, no. 7, pp. 2429-2433, 1999.

[97] C. T. Baldwin, F. Schwartz, J. Baima et al., "Identification of a polymorphic glutamic acid stretch in the $\alpha(2 \mathrm{~B})$ - adrenergic receptor and lack of linkage with essential hypertension," American Journal of Hypertension, vol. 12, no. 9 I, pp. 853-857, 1999.
[98] L. M. Ueno, E. S. T. Frazzatto, L. T. Batalha et al., “ $\alpha 2 B-$ Adrenergic receptor deletion polymorphism and cardiac autonomic nervous system responses to exercise in obese women," International Journal of Obesity, vol. 30, no. 2, pp. 214-220, 2006.

[99] J. P. Etzel, B. K. Rana, G. Wen et al., "Genetic variation at the human $\alpha 2 \mathrm{~B}$-adrenergic receptor locus: role in blood pressure variation and yohimbine response," Hypertension, vol. 45, no. 6, pp. 1207-1213, 2005.

[100] N. Suzuki, T. Matsunaga, K. Nagasumi et al., “ $\alpha 2 b$-Adrenergic receptor deletion polymorphism associates with autonomic nervous system activity in young healthy Japanese," Journal of Clinical Endocrinology \& Metabolism, vol. 88, no. 3, pp. 11841187, 2003.

[101] K. M. Small, K. M. Brown, S. L. Forbes, and S. B. Liggett, "Polymorphic deletion of three intracellular acidic residues of the alpha $2 \mathrm{~B}$-adrenergic receptor decreases $\mathrm{G}$ protein-coupled receptor kinase-mediated phosphorylation and desensitization," The Journal of Biological Chemistry, vol. 276, no. 7, pp. 4917-4922, 2001.

[102] J. P. Posti, L. Valve, S. Ruohonen, J. Akkila, M. Scheinin, and A. Snapir, "Dorsal hand vein responses to the $\alpha 1$-adrenoceptor agonist phenylephrine do not predict responses to the $\alpha 2$ adrenoceptor agonist dexmedetomidine," European Journal of Pharmacology, vol. 653, no. 1-3, pp. 70-74, 2011. 


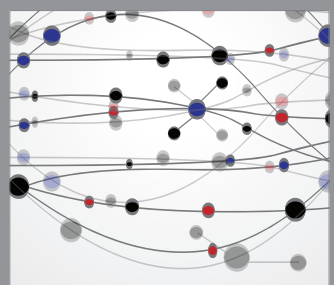

The Scientific World Journal
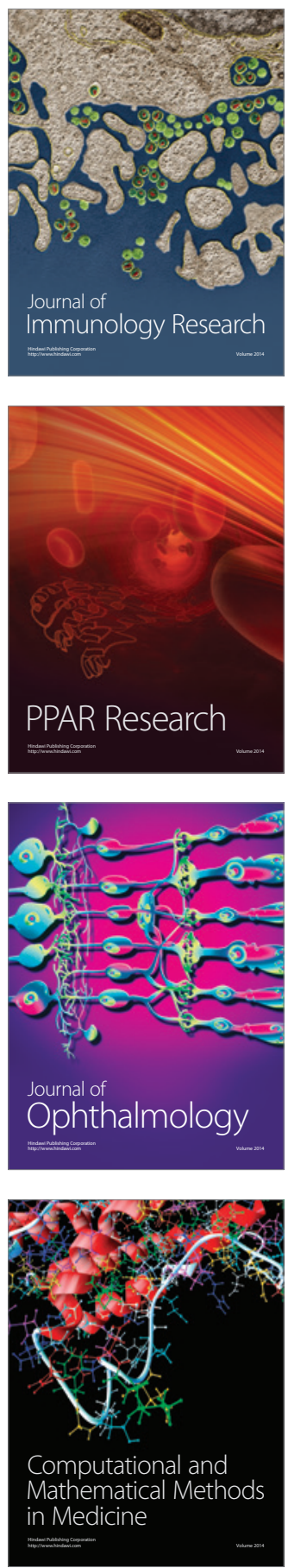

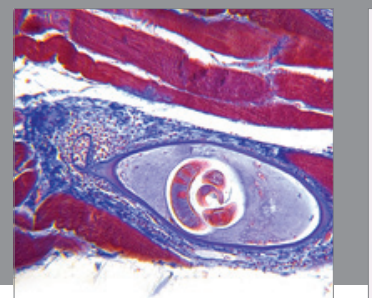

Gastroenterology

Research and Practice
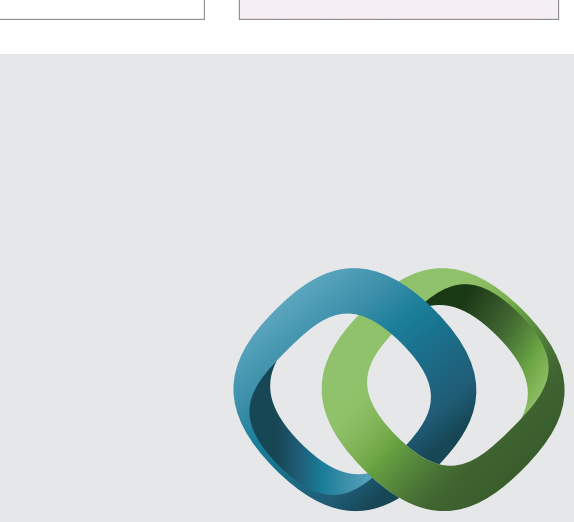

\section{Hindawi}

Submit your manuscripts at

http://www.hindawi.com
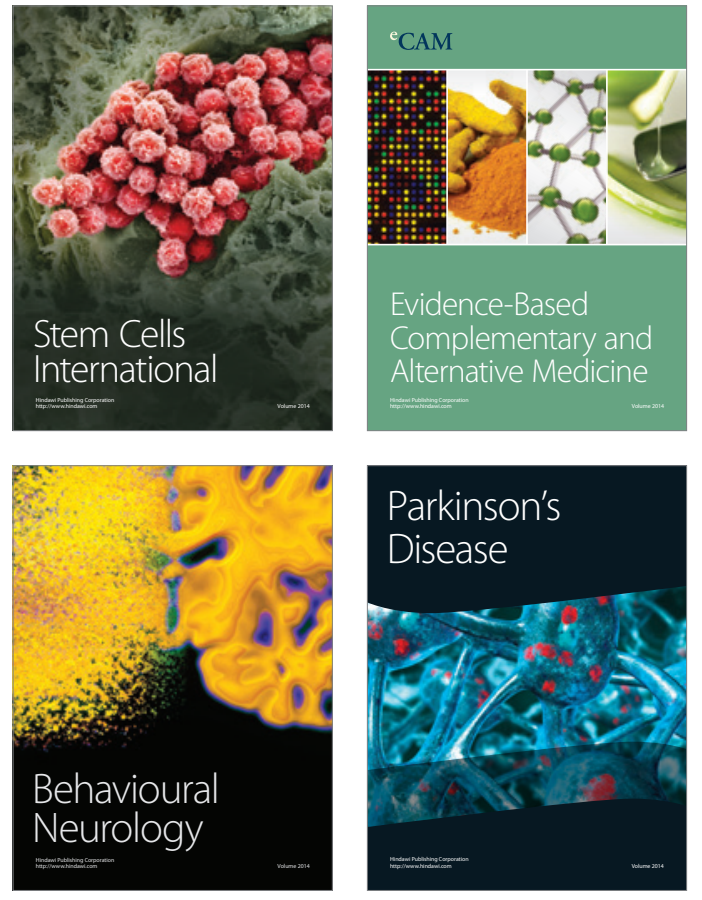
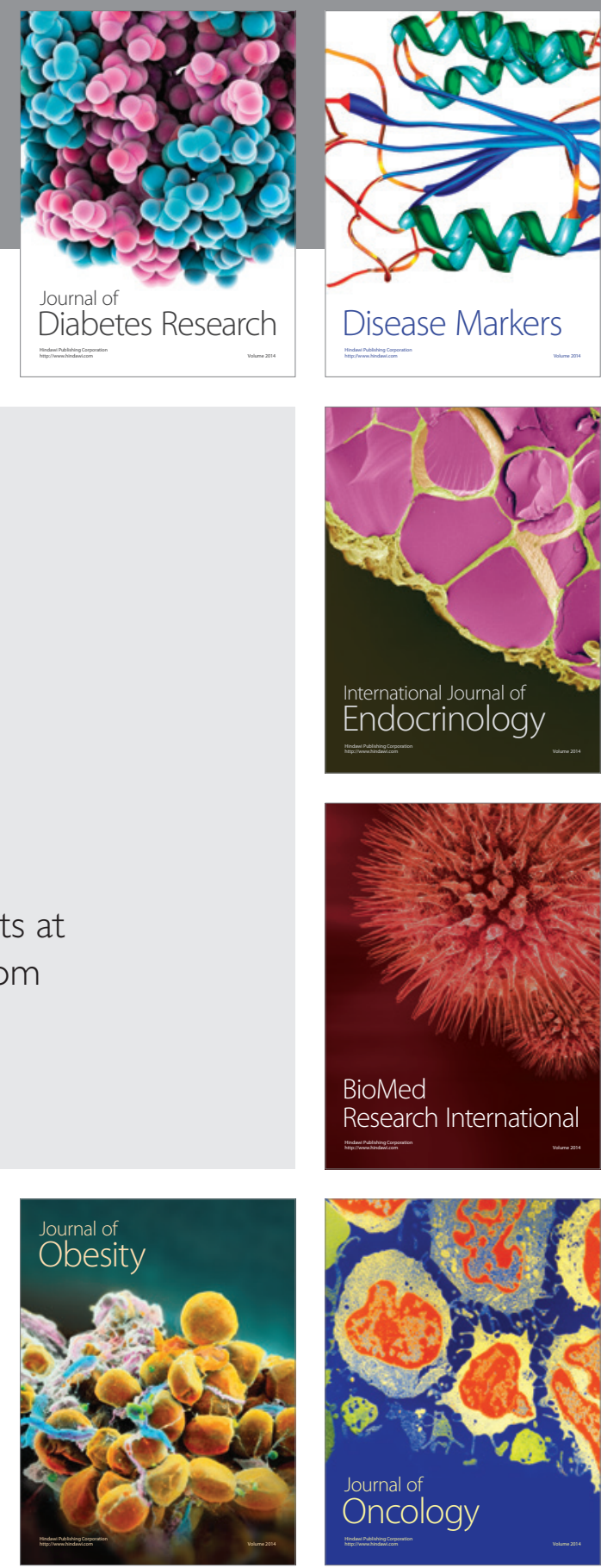

Disease Markers
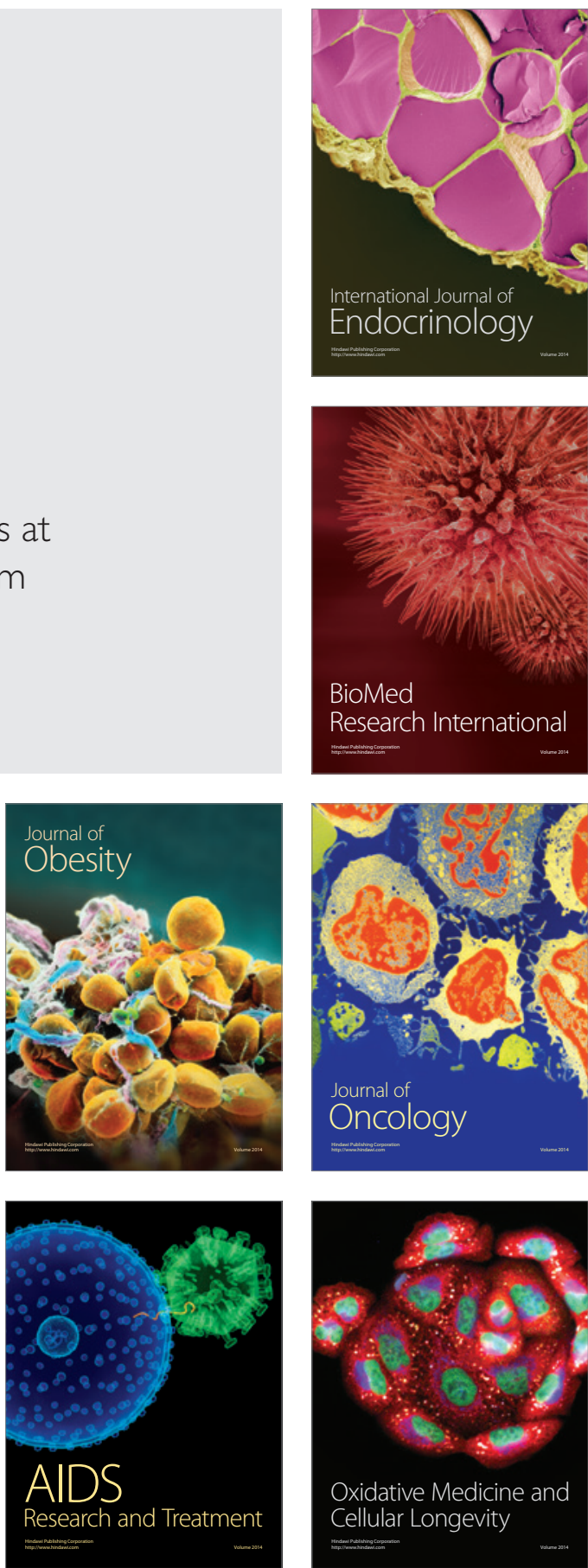